\title{
Physiological effects of copper on the freshwater alga Closterium ehrenbergii Meneghini (Conjugatophyceae) and its potential use in toxicity assessments
}

\author{
Hui Wang, Ramaraj Sathasivam and Jang-Seu Ki* \\ Department of Biotechnology, Sangmyung University, Seoul 03016, Korea
}

Although green algae of the genus Closterium are considered ideal models for testing toxicity in aquatic ecosystems, little data about the effects of toxicity on these algal species is currently available. Here, Closterium ehrenbergii was used to assess the acute toxicity of copper $(\mathrm{Cu})$. The median effective concentration $\left(\mathrm{EC}_{50}\right)$ of copper sulfate based on a dose response curve was $0.202 \mathrm{mg} \mathrm{L}^{-1}$, and reductions in photosynthetic efficiency $\left(F_{v} / F_{m}\right.$ ratio) of cells were observed in cultures exposed to $\mathrm{Cu}$ for $6 \mathrm{~h}$, with efficiency significantly reduced after $48 \mathrm{~h}(\mathrm{p}<0.01)$. In addition, production of reactive oxygen species significantly increased over time $(\mathrm{p}<0.01)$, leading to damage to intracellular organelles. Our results indicate that $\mathrm{Cu}$ induces oxidative stress in cellular metabolic processes and causes severe physiological damage within C. ehrenbergii cells, and even cell death; moreover, they clearly suggest that $C$. ehrenbergii represents a potentially powerful test model for use in aquatic toxicity assessments.

Key Words: chlorophyll fluorescence; Closterium ehrenbergii; copper; $\mathrm{EC}_{50}$; reactive oxygen species

\section{INTRODUCTION}

Microalgae play key roles in the primary productivity and biochemical cycles of aquatic systems. They are sensitive indicators of environmental change, and thus they have often been used to evaluate the impacts of metals, herbicides, and other pollutants in freshwater ecosystems (Qian et al. 2008); their physiology may be affected even under conditions of "no observable effect concentration" of a pollutant. In addition, the use of algae in toxicity assays confers numerous advantages: they are, for instance, easy to culture, requiring simple inorganic culture media, and they exhibit a rapid rate of growth and generational turnover (Lewis 1995).

Several physiological parameters are used as endpoints in algae-based ecotoxicological assessments, such as cell growth rate, biovolume, antioxidant system response, pigment production, and photosynthetic rate, which are compared and contrasted between treated and non-treated cells. Cell number is typically used as an indicator of growth in toxicological studies (Franklin et al. 2002), and many environmental contaminants affect the size and morphology of the tested cells via induction of oxidative stress (Sabatini et al. 2009). Chlorophyll autofluorescence (CAF) is an effective method for analyzing in situ photosynthetic efficiency, as well as to measure photosynthetic response to various stresses (Schreiber et al. 1995). Previous studies have reported the inhibition of microalgal photosynthesis by a wide variety of contaminants, leading to reductions in chlorophyll $a$ (Chl $a$ ) con-
(7) \$ This is an Open Access article distributed under the terms of the Creative Commons Attribution Non-Commercial License (http://creativecommons.org/licenses/by-nc/3.0/) which permits unrestricted non-commercial use, distribution, and reproduction in any medium, provided the original work is properly cited.
Received February 2, 2017, Accepted May 24, 2017

* Corresponding Author

E-mail: kijs@smu.ac.kr

Tel: +82-2-2287-5449, Fax: +82-2-2287-0070 
centrations (Ferrat et al. 2003), but little is known about the characteristics of CAF. Moreover, studies have shown that biochemical parameters play important roles in antioxidant defense systems in algal cells, which are estimated via antioxidant enzymatic assays (i.e., catalase, peroxidase, and superoxide dismutase) (Manimaran et al. 2012), but direct information about the formation of reactive oxygen species (ROS) in microalgae is scarce.

The unicellular green alga Closterium ehrenbergii is found in freshwater ecosystems worldwide (Ichimura and Kasai 1984). This species is crescent-shaped (long, curved, and tapered at both ends) and is typically much larger $(\sim 300 \mu \mathrm{m}$ in length) than most other unicellular microalgae (Lee et al. 2015), making observation of morphological and cellular changes relatively easy. It has long been used in research on algal sexual reproduction and cell cycling (e.g., Fukumoto et al. 1997), due to these features. In addition, previous studies have shown that $C$. ehrenbergii is very sensitive to a wide range of surfactants (Kim et al. 1998), and thus, recently it has been employed in additional toxicity evaluations and bioassays to detect the deleterious effects of hazardous substances on aquatic systems (Juneau et al. 2003, Sathasivam et al. 2016). However, to the best of our knowledge, there is little toxicological data available regarding the effects of various pollutants on Closterium species, and sensitivity of the species has not yet been compared to that of other microalgae (e.g., Aulacoseira granulate, Chlorella vulgaris, and Chlamydomonas sp.) by employing typical environmental contaminants, like heavy metals and pesticides.

In the present study, we quantified the sub-lethal effects of exposure to a well-known pollutant (copper, $\mathrm{Cu}$ ) on a variety of morphological and physiological parameters of a strain of the freshwater green alga C. ehrenbergii, focusing on chlorophyll fluorescence characteristics, photosynthetic efficiency, and ROS levels. We then investigated the potential of Korean C. ehrenbergii isolates as testing models for aquatic toxicity assessments via comparisons of the median effective concentrations $\left(\mathrm{EC}_{50}\right)$ of the test chemical copper sulfate $\left(\mathrm{CuSO}_{4}\right)$, which is widely used as a biocide for cleaning swimming pools, in aquaculture farms, and even for removing harmful algal blooms (Kim et al. 2007), despite evidence of contamination of aquatic ecosystems and possibly even drinking water.

\section{MATERIALS AND METHODS}

\section{Alga culture and median effective concentration $\left(\mathrm{EC}_{50}\right)$}

Cells of Korean C. ehrenbergii (Ce-01; Environmental Bio Inc., Seoul, Korea) were cultured in C medium (Watanabe et al. 2000) under conditions of $20 \pm 1^{\circ} \mathrm{C}$ ambient temperature, a $12: 12 \mathrm{~h}$ light-dark cycle, and a photon flux density of $\sim 65 \mu \mathrm{mol}$ photons $\mathrm{m}^{-2} \mathrm{~s}^{-1}$.

The effects of $\mathrm{Cu}$ toxicity on C. ehrenbergii was assessed using $\mathrm{CuSO}_{4}$ at concentrations of 0.1, 0.5, 1.0, 2.5, and $5.0 \mathrm{mg} \mathrm{L}^{-1}$. $\mathrm{CuSO}_{4}$ was procured from a commercial source (cat. No. C1297; Sigma, St. Louis, MO, USA) and prepared for standard stock solutions; all dilutions were prepared from standard stock solutions and all exposures were repeated in triplicate. The percentile inhibition and $72 \mathrm{~h}$ median effective concentration $\left(\mathrm{EC}_{50}-72 \mathrm{~h}\right)$ were calculated following the Organisation for Economic Cooperation and Development testing guidelines (OECD 2006), with $\mathrm{EC}_{50}-72 \mathrm{~h}$ estimates derived from a sigmoidal dose-response curve and plotted using Origin v. 8.5 software (MicroCal Software Inc., Northampton, MA, USA).

\section{Measurements of chlorophyll fluorescence}

Photosynthetic efficiency $\left(F_{v} / F_{m}\right)$ was measured using a Handy Plant Efficiency Analyser fluorometer (Hansatech Instruments Ltd., Norfolk, UK). To determine the photosynthetic parameters of C. ehrenbergii, $2 \mathrm{~mL}$ of each sample was collected using a specimen cup. The fluorescence parameters, minimal fluorescence in the darkadapted state $\left(F_{0}\right)$, maximal fluorescence in the darkadapted state $\left(F_{m}\right)$, and variable fluorescence $\left(F_{v} ; F_{m}-F_{o}\right)$, were measured at $0,6,24$, and $48 \mathrm{~h}$ following exposure to $\mathrm{Cu}$ concentrations of $0.1,0.2,0.4$, and $1.0 \mathrm{mg} \mathrm{L}^{-1}$. Values of $F_{v}$ and maximal quantum efficiency of photosystem II (PSII) photochemistry $\left(F_{v} / F_{m}\right)$ were then derived from $F_{o}$ and $F_{m}$.

\section{ROS measurement}

Dihydroxyrhodamine 123 (DHR123-D1054; Sigma) staining was used to measure ROS production, as DHR123 emits a green fluorescence when oxidized by ROS (Qin et al. 2008). Cells were independently treated with $0.2 \mathrm{mg}$ $\mathrm{L}^{-1} \mathrm{Cu}$, with incubation periods of 6,24 , and $48 \mathrm{~h}$. C. ehrenbergii cells were stained via exposure to DHR123 at a final concentration of $20 \mu \mathrm{M}$ for $1 \mathrm{~h}$, then harvested by centrifugation and twice rinsed with fresh $\mathrm{C}$ medium. 
The cultures were then re-suspended in fresh C medium, and mounted onto a slide and sealed; culture slides were observed with a fluorescence microscope (Carl Zeiss Axioskop, Oberkochen, Germany) to determine the level of ROS production in the cells. Image software $(\mathrm{NIH}$, Bethesda, MD, USA) was used to quantify relative CAF and ROS levels from the fluorescent microscopic images.

\section{Statistical analysis}

All data presented are mean values of triplicates. Oneway analysis of variance (ANOVA) with post hoc Student's Newmann-Keuls test using Graphpad InStat (Graphpad Software, Inc., San Diego, CA, USA) was used for comparisons between treated and untreated cultures, and $p$ $<0.05$ was used to determine significant differences between means.

\section{RESULTS AND DISCUSSION}

Chlorophyll pigments have often been used as indicators in the monitoring of environmental stressors of plants, including algae ( $\mathrm{Li}$ et al. 2005). Exposure of $\mathrm{Cu}$ to C. ehrenbergii induced a wide range of responses, depending on the $\mathrm{Cu}$ concentration; whereas exposure of $\mathrm{Cu}$ for $6 \mathrm{~h}$ at the initial experimental concentrations (i.e., 0.1-1.0 $\mathrm{mg} \mathrm{L}^{-1}$ ) had only slight effects on Chl $a$ levels (Fig. 1A), and Chl $a$ was significantly lower in cells exposed to relatively high concentrations of $\mathrm{Cu}\left(2.5\right.$ and $\left.5.0 \mathrm{mg} \mathrm{L}^{-1}\right)(\mathrm{p}$ $<0.05$ ). In addition, $\mathrm{Chl} a$ levels were markedly lower after exposed to $\mathrm{Cu}$ for $72 \mathrm{~h}$, with reductions of $12.1,91.3,98.2$, 98.1 , and $98.9 \%$ at $0.1,0.5,1.0,2.5$, and $5.0 \mathrm{mg} \mathrm{L}^{-1}$ of $\mathrm{Cu}$ concentrations, respectively. Similar results were reported by Chen et al. (2012), who found that $\mathrm{Chl} a$ concentrations significantly decreased in green algae exposed to $\mathrm{Cu}$, a trend that was associated with increasing $\mathrm{Cu}$ concentrations (from 2 to $10 \mu \mathrm{M}$ ). Likewise, exposure of $\mathrm{Cu}$ resulted in marked reductions in $\mathrm{Chl} a$ concentration in the dinoflagellate Cochlodinium polykrikoides, an effect that was also more pronounced at higher $\mathrm{Cu}$ concentrations (Ebenezer et al. 2014). Overall, these results clearly demonstrate that the Korean strain of C. ehrenbergii used in this study is considerably more sensitive to $\mathrm{Cu}$ than other microalgae that have been tested previously (Cairns et al. 1978, Viana and Rocha 2005, Ebenezer and Ki 2013, Ebenezer et al. 2014).

Estimations of $\mathrm{EC}_{50}$ values are useful for identifying environmental contaminants that may inhibit algal growth (Antón et al. 1993). The $\mathrm{EC}_{50}$ of Korean C. ehren-
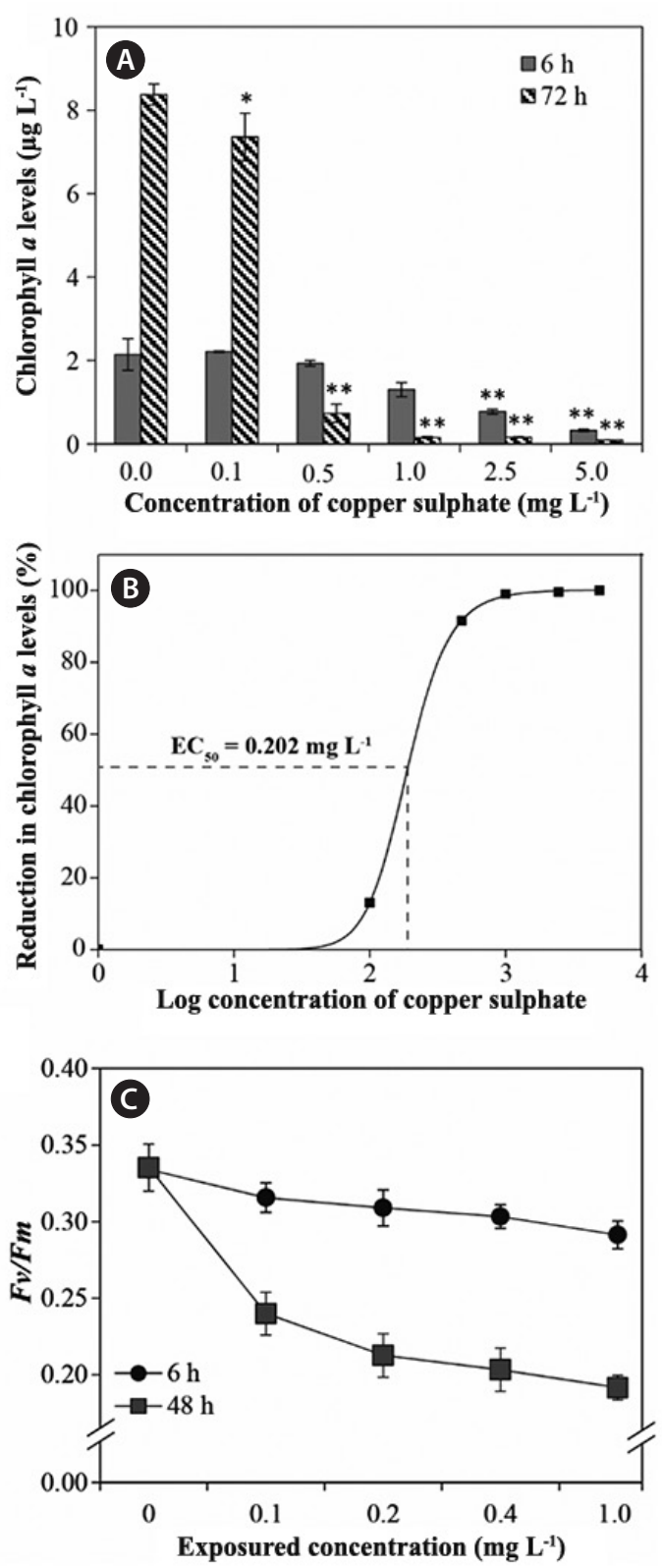

Fig. 1. Effect of different doses of copper to Closterium ehrenbergii. (A) Variation in chlorophyll $a(\mathrm{Chl} a)$ levels after 6 and $72 \mathrm{~h}$ exposure. (B) A dose response curve after $72 \mathrm{~h}$ exposure. (C) Variation in photosynthetic efficiency $\left(F_{v} / F_{m}\right.$ ratio) after 6 and $48 \mathrm{~h}$ exposure. Significant differences as determined by Student's Newmann-Keuls test are represented as ${ }^{*} p<0.05,{ }^{* *} p<0.01$ level. Error bars represent \pm standard deviation $(n=3)$.

bergii after exposure to $\mathrm{Cu}$ for $72 \mathrm{~h}$ was calculated 0.202 $\mathrm{mg} \mathrm{L}^{-1}$ (Fig. 1B). Previous studies have reported that $\mathrm{EC}_{50}$ for the green algae Chlorella ellipsoidea, Chlorella vulgaris, Chlamydomonas sp., and Tetraselmis suecica were $0.489,0.200,8.00$, and $43.03 \mathrm{mg} \mathrm{L}^{-1}$, respectively (Young and Lisk 1972, Cairns et al. 1978, Ebenezer and Ki 2013, 
Magdaleno et al. 2013). In addition, $\mathrm{EC}_{50}$ for diatoms Planothidium lanceolatum, Ditylum brightwellii, dinoflagellates C. polykrikoides, and Prorocentrum minimum after exposure to $\mathrm{Cu}$ were reported $0.620,0.406,0.633$, and 1.07 $\mathrm{mg} \mathrm{L}^{-1}$, respectively (Sbihi et al. 2012, Ebenezer et al. 2014, Guo et al. 2014, Lee et al. 2014). Comparisons of available $\mathrm{EC}_{50}$ values indicated that species used in this study was generally more sensitive to $\mathrm{Cu}$ than other algae (Table 1), suggesting that it is a reliable model organism for aquatic toxicity assessments (Kim et al. 1998, Juneau et al. 2003, Sathasivam et al. 2016).

In addition, most pollutants including heavy metals inhibit PSII activity and interfere with photosynthetic reactions (Giardi et al. 2001). The $F_{v} / F_{m}$ ratio is a useful and easily measurable parameter for the physiological state of the photosynthetic system in intact algae cells (Chen et al. 2012). To access the effects of $\mathrm{Cu}$ on the photosynthetic systems of C. ehrenbergii, we measured a range of parameters associated with photosynthetic processes. The fluorescence kinetic curves (both $F_{o}$ and $F_{m}$ ) generated in the present study gradually decreased with increasing $\mathrm{Cu}$ concentrations and exposured time (data not shown). $F_{v}$ $/ F_{m}$ of $C$. ehrenbergii was considerably affected by $\mathrm{Cu}$ toxicity and also declined with increasing $\mathrm{Cu}$ concentration and exposured time (Fig. 1C). Values of $F_{v} / F_{m}$ slightly fell after exposure for $6 \mathrm{~h}$ (Fig. 1C) but significantly declined after exposure for $48 \mathrm{~h}$ at all concentrations of $\mathrm{Cu}$, indicating that chlorophyll content and / or photosynthetic electron transport were inhibited by exposure to $\mathrm{Cu}$. Similar responses have been observed in other algae exposed to various environmental pollutants, although the extent of inhibition varied among species; for example, Mamboya et al. (1999) reported that the photosynthetic efficiency of

Table 1. The median effective concentration $\left(\mathrm{EC}_{50}\right)$ values of Closterium ehrenbergii and other microalgae after expose to copper

\begin{tabular}{lcl}
\hline \multicolumn{1}{c}{ Species } & $\begin{array}{c}\mathbf{E C}_{50} \\
\left(\mathbf{m g ~ L}^{-1}\right)\end{array}$ & \multicolumn{1}{c}{ Reference } \\
\hline $\begin{array}{l}\text { Green algae } \\
\text { Closterium ehrenbergii }\end{array}$ & 0.202 & This study \\
Chlorella vulgaris & 0.200 & Young and Lisk (1972) \\
Chlorella ellipsoidea & 0.489 & Magdaleno et al. (2013) \\
Chlamydomonas sp. & 8.00 & Cairns et al. (1978) \\
Tetraselmis suecica & 43.03 & Ebenezer and Ki (2013) \\
Diatom & & \\
Aulacoseira granulata & 2.58 & Viana and Rocha (2005) \\
$\begin{array}{l}\text { Ditylum brightwellii } \\
\text { Planothidium lanceolatum }\end{array}$ & 0.406 & Lee et al. (2014) \\
Dinoflagellate & 0.620 & Sbihi et al. (2012) \\
Cochlodinium polykrikoides & 0.633 & Ebenezer et al. (2014) \\
Prorocentrum minimum & 1.07 & Guo et al. (2014) \\
\hline
\end{tabular}

the brown alga Padina boergesenii significantly declined in response to increasing $\mathrm{Cu}$ concentration and exposured time. Moreover, in chlorophytes Chlorella vulgaris, Pseudokirchneriella subcapitata, dinoflagellates Cochlodinium polykrikoides, and P. minimum exposed to $3 \mu \mathrm{M}$, $250 \mu \mathrm{M}, 1.0 \mathrm{mg} \mathrm{L}^{-1}$, and $0.5 \mathrm{mg} \mathrm{L}^{-1}$ of $\mathrm{Cu}$, respectively, photosynthetic efficiency significantly declined in response to longer exposured times (Knauert and Knauer 2008, Guo et al. 2016a, 2016b). Such results not only demonstrate that exposure of $\mathrm{Cu}$ has an adverse effect on photosynthetic efficiency in many organisms, but also that the Korean C. ehrenbergii is a particularly sensitive to exposure of $\mathrm{Cu}$ (see Table 1 ).

Measurement of CAF is an efficient means of assessing physiological status in microalgae, which are capable of autofluorescence due to the presence of photosynthetic pigments (Trampe et al. 2011), as autofluorescence enables distinction between damaged and undamaged cells (Sato et al. 2004). As can be seen in Fig. 2A, relative CAF levels decreased with exposured time. In addition, ROS production for $C$. ehrenbergii was determined after exposure to $0.2 \mathrm{mg} \mathrm{L}^{-1} \mathrm{Cu}$ for 6,24 , and $48 \mathrm{~h}$ (Fig. 2B); compared to controls, red fluorescence (autofluorescence) significantly decreased, whereas green fluorescence slowly increased with increasing exposured time, suggesting overproduction of ROS after exposure to $\mathrm{Cu}$ (Fig. 2A \& B). The relative ROS level in C. ehrenbergii cells rose with increasing exposured time to $\mathrm{Cu}$ (Fig. 2B). Guo et al. (2014) reported that green fluorescence intensity significantly increased in the dinoflagellate $P$. minimum exposed to $\mathrm{CuSO}_{4}(\mathrm{p}<0.01)$, and gradually rose with increasing exposured time. In addition, Ishikawa et al. (1993) demonstrated that $\mathrm{H}_{2} \mathrm{O}_{2}$ is generated in chloroplasts and mitochondria, and immediately diffuses from these organelles to the cytosol. Algal cell toxicity can be promoted by the reaction of $\mathrm{Cu}$ (II) with $\mathrm{H}_{2} \mathrm{O}_{2}$, which further induces oxidative damage in algae cells (Chen et al. 2012). Moreover, we also observed changes in cell size and morphology, fragmentation of intracellular chloroplast in some algal cells, and loss of some cell contents (i.e., pigments) (Fig. $2 \mathrm{C}$ ); these observations are consistent with the harmful effects described above.

According to United States Environmental Protection Agency guidelines, the general standard for maximum discharge of $\mathrm{Cu}$ into the environment is $3.0 \mathrm{mg} \mathrm{L}^{-1}$ (U.S. EPA 1986); however, we found that growth rates, Chl $a$ levels, and photosynthetic efficiency were reduced, and ROS production enhanced for $C$. ehrenbergii exposed to levels of $\mathrm{Cu}$ as low as $1.0 \mathrm{mg} \mathrm{L}^{-1}$, with effects intensifying with increasing $\mathrm{Cu}$ concentrations. In a previous study, 


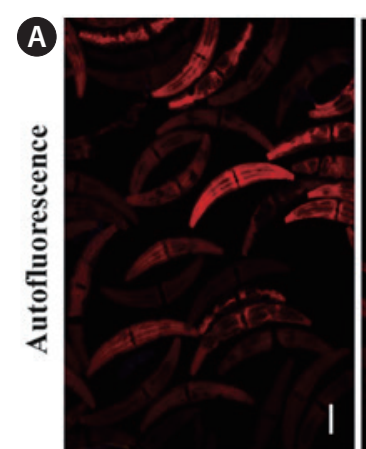

Control

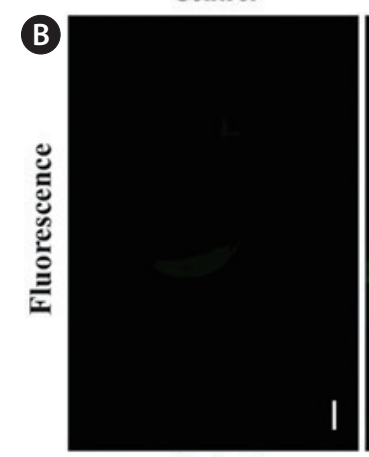

Control

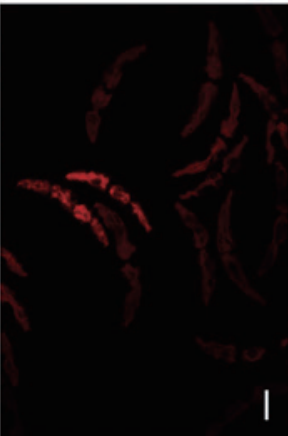

$6 \mathrm{~h}$

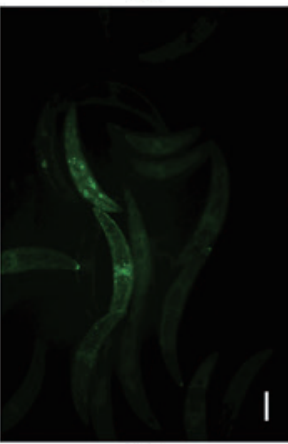

$6 \mathrm{~h}$

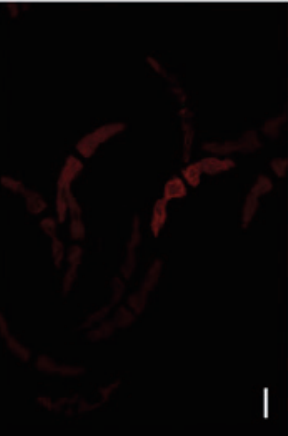

24 h

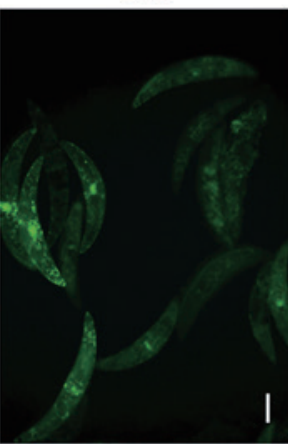

$24 \mathrm{~h}$

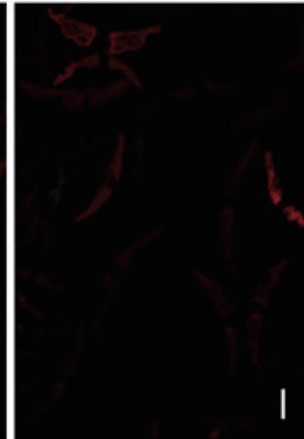

$48 \mathrm{~h}$

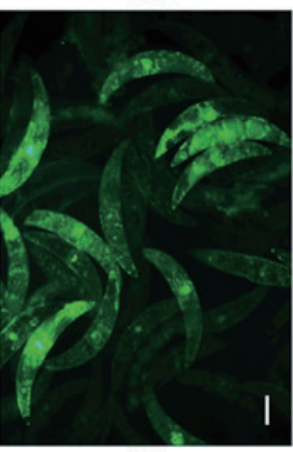

$48 \mathrm{~h}$
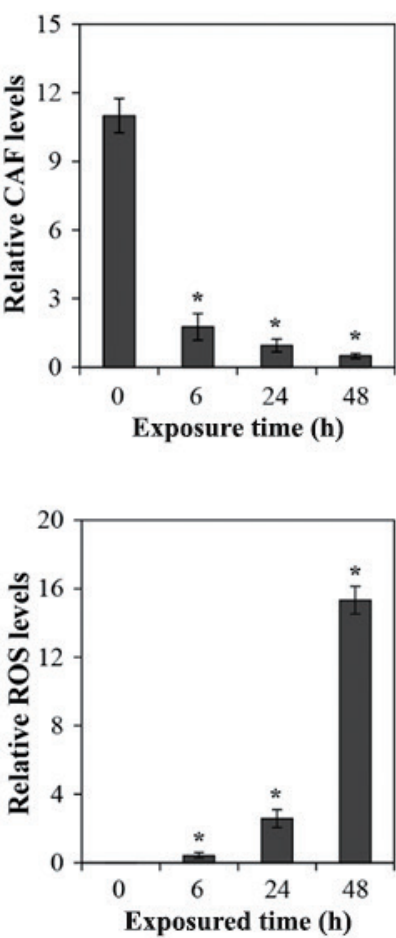

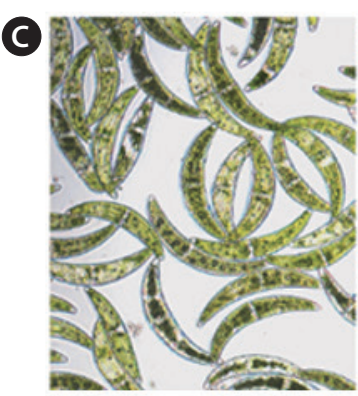

Control

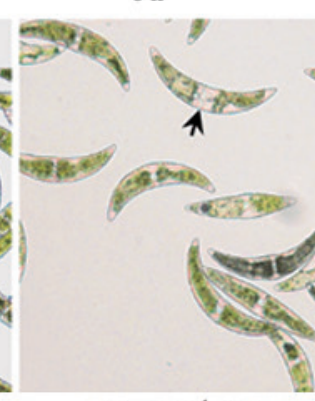

$0.2 \mathrm{mg} \mathrm{L}^{-1}, 6 \mathrm{~h}$

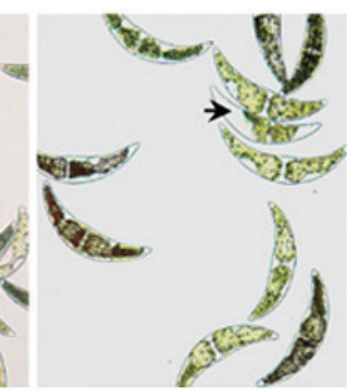

$0.2 \mathrm{mg} \mathrm{L}^{-1}, 48 \mathrm{~h}$

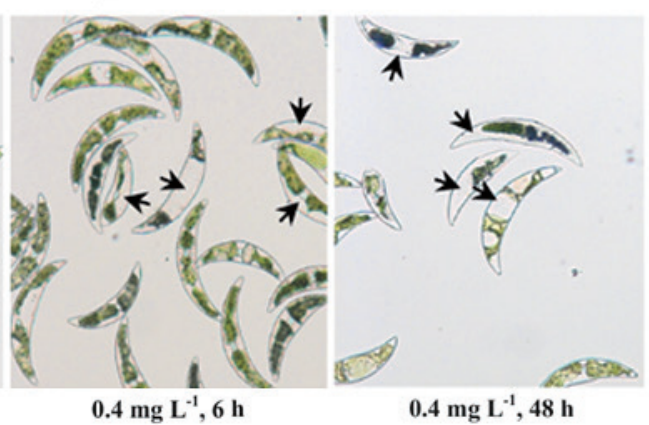

Fig. 2. Relative chlorophyll autofluorescence (CAF) levels (A) and reactive oxygen species (ROS) production (B) of Closterium ehrenbergii after expose to $0.2 \mathrm{mg} \mathrm{L}^{-1}$ copper at different intervals $(6,24$, and $48 \mathrm{~h}$ ). (C) Morphological changes of Closterium ehrenbergii after 6 and $48 \mathrm{~h}$ exposure to 0.2 and $0.4 \mathrm{mg} \mathrm{L}^{-1}$ of copper as seen by light microscope. Arrows represent chloroplast damage or loss of pigment. Significant differences as determined by Student's Newmann-Keuls test are represented as ${ }^{*} \mathrm{p}<0.01$ level. Error bars represent \pm standard deviation $(\mathrm{n}=10)$. Scale bars represent: $A \& B, 50 \mu \mathrm{m}$.

Sathasivam et al. (2016) demonstrated that growth rates, cell division, pigment levels, and CAF intensity decreased for Korean C. ehrenbergii exposed to $\mathrm{NaOCl}$, whereas production of antioxidant enzymes increased, even at relatively lower contaminant concentrations. Moreover, expression of many stress-related genes (i.e., heat shock proteins, superoxide dismutase, glutathione S-transferase) increased for C. ehrenbergii exposed to $\mathrm{Cu}$ and other environmental pollutants (unpublished data). It is clear that C. ehrenbergii is extremely sensitive to a variety of environmental contaminants, and that the discharge limit for $\mathrm{Cu}$ concentrations established by the U. S. EPA is not low enough to avoid damage to the green alga C. ehrenbergii and possibly to other microalgae in environments.

\section{CONCLUSION}

The Korean freshwater green alga C. ehrenbergii exhibited a dose-dependent response when exposed to a typical pollutant copper. Comparisons of C. ehrenbergii's $\mathrm{EC}_{50}$ values $\left(0.202 \mathrm{mg} \mathrm{L}^{-1}\right)$ to those of other organisms clearly demonstrated this species extreme sensitivity to Cu exposure. In addition, exposure to $1.0 \mathrm{mg} \mathrm{L}^{-1}$ of $\mathrm{Cu}$ significantly 
inhibits production of Chl $a$, reduces photosynthetic efficiency, and induces the generation of intracellular ROS, which may disrupt cell membrane functioning to cell death. General discharge standards of Korea limit Cu concentrations to $3.0 \mathrm{mg} \mathrm{L}^{-1}$, and thus this level may be high enough to potentially cause severe harmful to C. ehrenbergii and other aquatic organisms. From these results, we can conclude that the Korean C. ehrenbergii strain represents a useful model organism for aquatic toxicity assessments, and as such can provide a wealth of information pertinent to general risk assessments.

\section{ACKNOWLEDGEMENTS}

We thank Drs. R. Guo and V. Evenezer for culture and experimental assistants. This work was supported by the National Research Foundation of Korea Grant funded by the Korean Government (2015M1A5A1041805 and 2016R1D1A1A09920198).

\section{REFERENCES}

Antón, F. A., Laborda, E. \& Laborda, P. 1993. Acute toxicity of technical captan to algae and fish. Bull. Environ. Contam. Toxicol. 50:392-399.

Cairns, J., Buikema, A. L., Heath, A. G. \& Parker, B. C. 1978. Effects of temperature on aquatic organism sensitivity to selected chemicals. Bulletin 106. Virginia Water Resources Research Center, Blacksburg, VA, 88 pp.

Chen, H., Chen, J., Guo, Y., Wen, Y., Liu, J. \& Liu, W. 2012. Evaluation of the role of the glutathione redox cycle in $\mathrm{Cu}$ (II) toxicity to green algae by a chiral perturbation approach. Aquat. Toxicol. 120-121:19-26.

Ebenezer, V. \& Ki, J. -S. 2013. Quantification of the sub-lethal toxicity of metals and endocrine-disrupting chemicals to the marine green microalga Tetraselmis suecica. Fish. Aquat. Sci. 16:187-194.

Ebenezer, V., Lim, W. A. \& Ki, J. -S. 2014. Effects of the algicides $\mathrm{CuSO}_{4}$ and $\mathrm{NaOCl}$ on various physiological parameters in the harmful dinoflagellate Cochlodinium polykrikoides. J. Appl. Phycol. 26:2357-2365.

Ferrat, L., Pergent-Martini, C. \& Roméo, M. 2003. Assessment of the use of biomarkers in aquatic plants for the evaluation of environmental quality: application to seagrasses. Aquat. Toxicol. 65:187-204.

Franklin, N. M., Stauber, J. L., Apte, S. C. \& Lim, R. P. 2002. Effect of initial cell density on the bioavailability and toxicity of copper in microalgal bioassays. Environ. Toxicol.
Chem. 21:742-751.

Fukumoto, R. -H., Fujii, T. \& Sekimoto, H. 1997. Detection and evaluation of a novel sexual pheromone that induces sexual cell division of Closterium ehrenbergii (Chlorophyta). J. Phycol. 33:441-445.

Giardi, M. T., Koblízek, M. \& Masojídek, J. 2001. Photosystem II-based biosensors for the detection of pollutants. Biosens. Bioelectron. 16:1027-1033.

Guo, R., Ebenezer, V. \& Ki, J. -S. 2014. PmMGST3, a novel microsomal glutathione S-transferase gene in the dinoflagellate Prorocentrum minimum, is a potential biomarker of oxidative stress. Gene 546:378-385.

Guo, R., Lim, W. -A. \& Ki, J. -S. 2016a. Genome-wide analysis of transcription and photosynthesis inhibition in the harmful dinoflagellate Prorocentrum minimum in response to the biocide copper sulfate. Harmful Algae 57:27-38.

Guo, R., Wang, H., Suh, Y. S. \& Ki, J. -S. 2016b. Transcriptomic profiles reveal the genome-wide responses of the harmful dinoflagellate Cochlodinium polykrikoides when exposed to the algicide copper sulfate. BMC Genomics 17:29.

Ichimura, T. \& Kasai, F. 1984. Post-zygotic isolation between allopatric mating groups of Closterium ehrenbergii Meneghini (Conjugatophyceae). Phycologia 23:77-85.

Ishikawa, T., Takeda, T., Shigeoka, S., Hirayama, O. \& Mitsunaga, T. 1993. Hydrogen peroxide generation in organelles of Euglena gracilis. Phytochemistry 33:1297-1299.

Juneau, P., Sumitomo, H., Matsui, S., Itoh, S., Kim, S. -G. \& Popovic, R. 2003. Use of chlorophyll fluorescence of Closterium ehrenbergii and Lemna gibba for toxic effect evaluation of sewage treatment plant effluent and its hydrophobic components. Ecotoxicol. Environ. Saf. 55:1-8.

Kim, J. -D., Kim, B. \& Lee, C. -G. 2007. Alga-lytic activity of Pseudomonas fluorescens against the red tide causing marine alga Heterosigma akashiwo (Raphidophyceae). Biol. Control 41:296-303.

Kim, S. -G., Matsui, S. \& Hamada, J. 1998. Toxicity test of anionic and nonionic surfactants to Closterium ehrenbergii by new indexes. J. Environ. Conserv. Eng. 27:274-281.

Knauert, S. \& Knauer, K. 2008. The role of reactive oxygen species in copper toxicity to two freshwater green algae. J. Phycol. 44:311-319.

Lee, M. -A., Guo, R., Ebenezer, V. \& Ki, J. -S. 2015. Evaluation and selection of reference genes for ecotoxicogenomic study of the green alga Closterium ehrenbergii using quantitative real-time PCR. Ecotoxicology 24:863-872.

Lee, M. -A., Guo, R. \& Ki, J. -S. 2014. Different transcriptional responses of heat shock protein 20 in the marine diatom Ditylum brightwellii exposed to metals and endocrine- 
disrupting chemicals. Environ. Toxicol. 29:1379-1389.

Lewis, M. A. 1995. Algae and vascular plant tests. In Rand, G. M. (Ed.) Fundamentals of Aquatic Toxicology: Effects, Environmental Fate, and Risk Assessment. Taylor and Francis, Washington, DC, pp. 135-169.

Li, X., Ping, X., Xiumei, S., Zhenbin, W. \& Liqiang, X. 2005. Toxicity of cypermethrin on growth, pigments, and superoxide dismutase of Scenedesmus obliquus. Ecotoxicol. Environ. Saf. 60:188-192.

Magdaleno, A., Vélez, C. G., Wenzel, M. T. \& Tell, G. 2013. Effects of cadmium, copper and zinc on growth of four isolated algae from a highly polluted Argentina river. Bull. Environ. Contam. Toxicol. 92:202-207.

Mamboya, F. A., Pratap, H. B., Mtolera, M. \& Björk, M. 1999. The effect of copper on the daily growth rate and photosynthetic efficiency of the brown macroalga Padina boergesenii. In Richmond, M. D. \& Francis, J. (Eds.) Proceedings of the 20th Anniversary Conference on Advances on Marine Sciences in Tanzania, IMS/WIOMSA, Zanzibar, pp. 185-192.

Manimaran, K., Karthikeyan, P., Ashokkumar, S., Ashok Prabu, V. \& Sampathkumar, P. 2012. Effect of copper on growth and enzyme activities of marine diatom, Odontella mobiliensis. Bull. Environ. Contam. Toxicol. 88:3037.

OECD. 2006. OECD guidelines for the testing of chemicals. Test No. 201. Freshwater algal and cyanobacteria, growth inhibition test. OECD Publications, Paris, $25 \mathrm{pp}$.

Qian, H., Chen, W., Sheng, G. D., Xu, X., Liu, W. \& Fu, Z. 2008. Effects of glufosinate on antioxidant enzymes, subcellular structure, and gene expression in the unicellular green alga Chlorella vulgaris. Aquat. Toxicol. 88:301-307.

Qin, Y., Lu, M. \& Gong, X. 2008. Dihydrorhodamine 123 is superior to 2,7-dichlorodihydrofluorescein diacetate and dihydrorhodamine $6 \mathrm{G}$ in detecting intracellular hydrogen peroxide in tumor cells. Cell Biol. Int. 32:224-228.

Sabatini, S. E., Juárez, Á. B., Eppis, M. R., Bianchi, L., Luquet, C. M. \& Ríos de Molinaa, M. C. 2009. Oxidative stress and antioxidant defences in two green microalgae exposed to copper. Ecotoxicol. Environ. Saf. 72:1200-1206.

Sathasivam, R., Ebenezer, V., Guo, R. \& Ki, J. -S. 2016. Physiological and biochemical responses of the freshwater green algae Closterium ehrenbergii to the common disinfectant chlorine. Ecotoxicol. Environ. Saf. 133:501-508.

Sato, M., Murata, Y., Mizusawa, M., Iwahashi, H. \& Oka, S. -I. 2004. A simple and rapid dual-fluorescence viability assay for microalgae. Microbiol. Cult. Coll. 20:53-59.

Sbihi, K., Cherifi, O., El gharmali, A., Oudra, B. \& Aziz, F. 2012. Accumulation and toxicological effects of cadmium, copper and zinc on the growth and photosynthesis of the freshwater diatom Planothidium lanceolatum (Brébisson) Lange-Bertalot: a laboratory study. J. Mater. Environ. Sci. 3:497-506.

Schreiber, U., Hormann, H., Neubauer, C. \& Klughammer, C. 1995. Assessment of photosystem II photochemical quantum yield by chlorophyll fluorescence quenching analysis. Aust. J. Plant Physiol. 22:209-220.

Trampe, E., Kolbowski, J., Schreiber, U. \& Kühl, M. 2011. Rapid assessment of different oxygenic phototrophs and single-cell photosynthesis with multicolour variable chlorophyll fluorescence imaging. Mar. Biol. 158:16671675.

U.S. Environmental Protection Agency. 1986. Environmental standards. General standards: General standards for discharge of environmental pollutant. Available from: http://ercmp.nic.in/Documents/GenEnvStandard.pdf. Accessed Apr 2, 2017.

Viana, S. M. \& Rocha, O. 2005. The toxicity of copper sulphate and atrazine to the diatom Aulacoseira Granulata (Ehrenberg) Simmons. Acta Limnol. Bras. 17:291-300.

Watanabe, M. M., Kawachi, M., Hiroki, M. \& Kasai, F. 2000. NIES collection list of strains. 6th ed. 2000 microalgae and protozoa. Microbial Culture Collections, National Institute for Environmental Studies, Tsukuba, 159 pp.

Young, R. G. \& Lisk, D. J. 1972. Effect of copper and silver ions on algae. J. Water Pollut. Control Fed. 44:1643-1647. 